\title{
Bat origin of human coronaviruses
}

\author{
Ben $\mathrm{Hu}^{1}$, Xingyi $\mathrm{Ge}^{1}$, Lin-Fa Wang ${ }^{2}$ and Zhengli Shi ${ }^{\text {* }^{*}}$
}

\begin{abstract}
Bats have been recognized as the natural reservoirs of a large variety of viruses. Special attention has been paid to bat coronaviruses as the two emerging coronaviruses which have caused unexpected human disease outbreaks in the 21st century, Severe Acute Respiratory Syndrome Coronavirus (SARS-CoV) and Middle East Respiratory Syndrome Coronavirus (MERS-CoV), are suggested to be originated from bats. Various species of horseshoe bats in China have been found to harbor genetically diverse SARS-like coronaviruses. Some strains are highly similar to SARS-CoV even in the spike protein and are able to use the same receptor as SARS-CoV for cell entry. On the other hand, diverse coronaviruses phylogenetically related to MERS-CoV have been discovered worldwide in a wide range of bat species, some of which can be classified to the same coronavirus species as MERS-CoV. Coronaviruses genetically related to human coronavirus 229E and NL63 have been detected in bats as well. Moreover, intermediate hosts are believed to play an important role in the transmission and emergence of these coronaviruses from bats to humans. Understanding the bat origin of human coronaviruses is helpful for the prediction and prevention of another pandemic emergence in the future.
\end{abstract}

Keywords: Bats, SARS, MERS, Coronavirus, Emerging infectious diseases

\section{Background}

Bats, with extensive geographical distribution and capability of flight, constitute the second largest group of mammalian species and have been documented as natural hosts of a large number of diverse viruses such as lyssaviruses, paramyxoviruses and filoviruses $[1,2]$. In the past decade, numerous novel coronaviruses have been discovered in a wide variety of bat species throughout Asia, Europe, Africa and America [3]. Within the coronavirus genera Alphacoronavirus and Betacoronavirus, which mainly infect mammals, 7 out of the 15 currently assigned viral species have only been found in bats [4]. It is proposed that bats are major hosts for alphacoronaviruses and betacoronaviruses and play an important role as the gene source in the evolution of these two coronavirus genera [5]. Among the coronaviruses harbored by bats, some have drawn particular research interests, as they have been found to be associated with two high profile human disease outbreaks, Severe Acute Respiratory

\footnotetext{
* Correspondence: zlshi@wh.iov.cn

${ }^{1}$ Key Laboratory of Special Pathogens and Center for Emerging Infectious Diseases, Wuhan Institute of Virology, Chinese Academy of Sciences, Wuhan, China

Full list of author information is available at the end of the article
}

Syndrome (SARS) and Middle East Respiratory Syndrome (MERS).

In this review, we focus on the emerging coronaviruses putatively linked to a zoonotic origin from bats, represented by SARS coronavirus (SARS-CoV) and MERS coronavirus (MERS-CoV). We present an overview of current evidence for bat origin of these two viruses and also discuss how the spillover events of coronavirus from animals to humans may have happened. Considering that bats have been known to harbor more coronaviruses than any other species, it is likely that SARS-CoV and MERS$\mathrm{CoV}$ won't be the only bat coronaviruses to jump among species and cause human infections. Bat coronaviruses should be seriously regarded in light of their potential risks to public health.

\section{Emergence of SARS and MERS}

SARS first emerged in late 2002 in Guangdong Province, southern China, as a novel clinical severe disease (termed "atypical pneumonia") marked by fever, headache and subsequent onset of respiratory symptoms including cough, dyspnea and pneumonia. Being highly transmissible among humans, SARS rapidly spread to Hong Kong and other provinces across China and then to other 28 countries [6, 7]. By July 2003, it had caused
C Biomed Central

(c) $2015 \mathrm{Hu}$ et al. Open Access This article is distributed under the terms of the Creative Commons Attribution 4.0 International License (http://creativecommons.org/licenses/by/4.0/), which permits unrestricted use, distribution, and reproduction in any medium, provided you give appropriate credit to the original author(s) and the source, provide a link to the Creative Commons license, and indicate if changes were made. The Creative Commons Public Domain Dedication waiver (http://creativecommons.org/publicdomain/zero/1.0/) applies to the data made available in this article, unless otherwise stated. 
8096 confirmed cases of infection in 29 countries, 774 (9.6\%) of which were fatal (http://www.who.int/csr/sars/ country/table2004_04_21/en/). The second outbreak in 2004 only caused 4 infections with no mortality nor further transmission [8].

The MERS epidemic emerged in the Kingdom of Saudi Arabia (KSA) since June 2012, with a similar clinical syndrome to SARS but seemingly less transmissible. In addition to respiratory illness, renal failure was identified in some severe cases [9-11]. Unlike SARS which had numerous super-spreader events, most MERS cases were independent clusters and limited to countries in the Middle East, particularly in KSA. Limited MERS cases have been reported in African and European countries and the United States of America, but exclusively in individuals travelling back from the Middle East. Some patients were reported to have a history of contact with camels while many other cases lacked this epidemiological link [9-11]. The MERS pandemic in the Republic of Korea in 2015 was caused by a single person who returned from travel in the Middle East. This made the Republic of Korea to be home to the second largest MERS epidemic with a total of 185 confirmed cases and 36 deaths [11, 12]. By 18 August 2015 a total of 1413 laboratory-confirmed cases of MERS have been reported worldwide with a median age of 50 years, including 502 related deaths. The mortality of MERS (approximately $35 \%$ ) is much higher than that of SARS (around $10 \%$ ).

\section{SARS-CoV and MERS-CoV represent two different species in the genus Betacoronavirus \\ Genomic structure and taxonomic classification}

SARS-CoV and MERS-CoV share similar genome organization with other coronaviruses, but display unique genomic structures and evolutionary lineages. The coronavirus genome possesses 6-to-7 major open reading frames (ORFs) in the characteristic gene order in the 5 to 3' direction: ORF1a and $1 \mathrm{~b}$ which comprise two-thirds of the genome and encode the nonstructural polyproteins, and four ORFs downstream that encode structural proteins: spike protein $(S)$, envelope protein $(E)$, membrane protein $(\mathrm{M})$ and nucleocapsid protein $(\mathrm{N})$. Some coronaviruses have a hemagglutinin-esterase (HE) gene between ORF1b and S. Besides the coronavirus-conserved genes, the SARS-CoV genome contains a number of specific accessory genes including ORF3a, 3b, ORF6, ORF7a, 7b, ORF8a, 8b and 9b [13-15]. Comparably, MERS-CoV encodes five unique accessory genes, designated ORF3, ORF4a, ORF4b, ORF5 and ORF8b. None of these genes have been shown to be related to other known coronavirus genes at the time of discovery $[16,17]$. MERS-CoV was found to have 75 and $77 \%$ amino acid (aa) sequence identity in 7 conserved replicase genes with two previously identified bat coronaviruses: BtCoV-HKU4 and BtCoV-HKU5. Based on the classification criteria of the the International Committee on Taxonomy of Viruses (ICTV), SARS-CoV and MERS-CoV represent two novel distinct coronavirus species in the genus Betacoronavirus (Fig. 1a and Table 1) [10, 18, 19]. Members of betacoronaviruses are separated into four lineages, A, B, C and D. SARS-CoV and MERS-CoV are clustered in lineage $B$ and $C$, respectively [18].

\section{Receptor usage}

The $\mathrm{S}$ protein of coronaviruses is a surface-located trimeric glycoprotein consisting of two subunits: the $\mathrm{N}$-terminal S1 subunit and the C-terminal S2 subunit. The $\mathrm{S} 1$ subunit specializes in recognizing and binding to the host cell receptor while the S2 region is responsible for membrane fusion. Compared with the S2, the S1 subunit shows much higher variability [20]. Owing to its function of receptor binding, the variation in $S$ protein defines in large part the tissue tropism and host range of different coronaviruses [21].

Angiotensin-converting enzyme 2 (ACE2) was identified to be the functional receptor of SARS-CoV [22-24]. A 193 aa fragment (aa 318-510) of SARS-CoV S protein was demonstrated to bind ACE2 more efficiently than the full S1 domain and was defined as the receptorbinding domain (RBD) of SARS-CoV [25]. A loop subdomain (aa 424-494) that directly contacts with ACE2 was further identified as the receptor-binding motif (RBM) by crystal structure analysis [26]. In the RBM, several aa residues were found to be critical for receptor binding and changes in these key residues resulted in different binding efficiency among different SARS-CoV isolates [26-28].

Dipeptidyl peptidase 4 (DPP4, also known as CD26) was identified as a functional receptor for MERS-CoV [29] and it is relatively conserved among mammalian species. Published results indicated that MERS-CoV can infect and replicate in most cell lines derived from human, non-human primate, bat, swine, goat, horse, rabbit, civet, and camel, but not from mice, hamster, dog, ferret, and cat [29-36]. DPP4 from camel, goat, cow, and sheep can be also recognized by MERS-CoV and can support MERS-CoV replication [30, 35]. Resolved crystal structures demonstrate that DPP4recognizing $\mathrm{RBD}$ is localized to the $\mathrm{S} 1 \mathrm{C}$-terminal portion of S protein of MERS-CoV [37-39]. The RBD of MERS-CoV consists of $\sim 240$ residues, spanning aa 367-606, which fold into a structure consisting of two subdomains, the core subdomain and the external subdomain. The core subdomain of MERS-CoV RBD is structurally similar to that of the SARS-CoV RBD, but the external subdomain (also named as RBM) is different to that of the SARS-CoV [37-39]. 


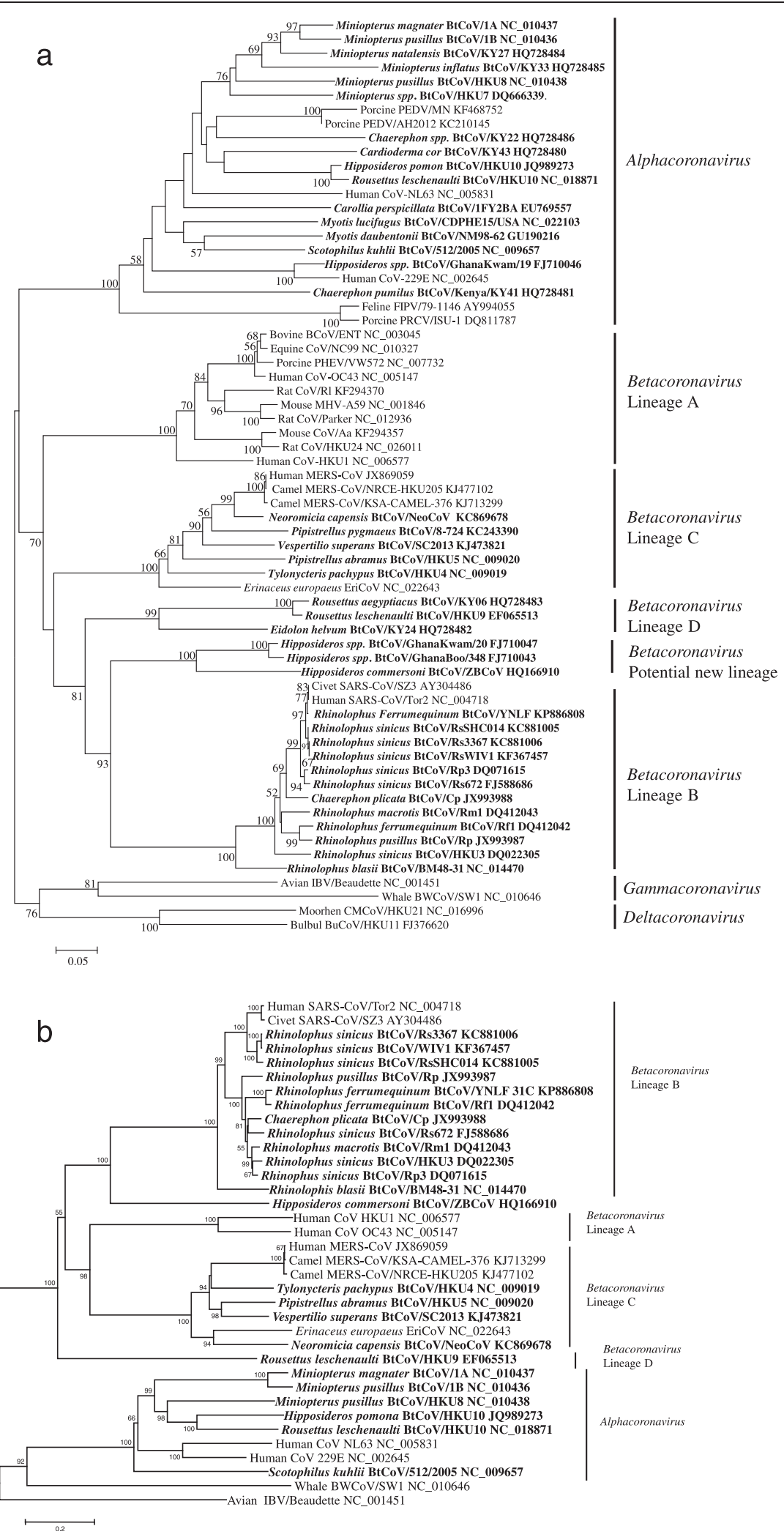

Fig. 1 (See legend on next page.) 
(See figure on previous page.)

Fig. 1 Phylogenetic analysis of bat coronaviruses with other coronaviruses. The phylogenetic tree was constructed based on 816-nt partial RdRp sequences (a) and full-length spike protein sequences (b). Available sequences were retrieved from GenBank and aligned using ClustalW. The alignment was used to construct tree by MEGA (Version 5.1) with the neighbor-joining statistical method. Bootstrap values were calculated from 1000 replicates (values $\geq 50$ are shown). Bat coronaviruses are drawn in bold and named following bat species, plus BtCoV, strain name, and GenBank accession number

\section{Bat origin of SARS-CoV}

\section{Civets are intermediate and trasnmission host of SARS-CoV}

Epidemiological survey showed that early cases of SARS in 2002-2003 and all 4 cases in 2003-2004 had a history of animal contact through animal trade in wet markets or in restaurants where live animals were kept in Guangdong Province. Molecular detection and virus isolation studies suggested that the pandemic-causing SARS-CoV originated from traded civets in wet markets. This was indirectly confirmed by the massive culling of market civets, which was believed to play a major role in efficiently containing the SARS pandemics and no further SARS case was reported after 2004 [40-42].
However, subsequent extensive epidemiology studies did not find SARS-CoV in farmed or wild-caught civets, indicating that other animal(s) was involved in SARS$\mathrm{CoV}$ transmission in the animal market or other trading activities and civets are unlikely the natural reservoir of SARS-CoV [43-45].

\section{Discovery of diverse SARS-like coronaviruses in bats}

Several years before the outbreak of SARS, two other zoonotic viruses, Nipah virus and Hendra virus, emerged in Asia and Australia and they were both known to be originated from bats $[46,47]$. These led scientists to consider bats in the search of reservoirs of SARS-CoV.

Table 1 Comparison of bat coronaviruses with SARS-CoV or MERS-CoV in conserved replicase domains and structural proteins

\begin{tabular}{|c|c|c|c|c|c|c|c|c|c|c|c|c|c|c|}
\hline \multirow[t]{2}{*}{ CoV strain } & \multirow[t]{2}{*}{ Bat species } & \multirow[t]{2}{*}{ Country } & \multicolumn{12}{|c|}{$\%$ amino acid sequence identity ${ }^{a}$ with SARS-CoV or MERS-CoV } \\
\hline & & & ADRP & 3CLpro & $\mathrm{RdRp}$ & $\mathrm{Hel}$ & ExoN & NendoU & OMT & $\begin{array}{l}\text { Concatenated } \\
\text { domains }^{@}\end{array}$ & $\mathrm{~S}$ & $E$ & $M$ & $\mathrm{~N}$ \\
\hline HKU3 & Rhinolophus sinicus & China & 92.0 & 99.3 & 98.6 & 99.2 & 98.1 & 98.0 & 98.3 & 96.0 & 79.7 & 100 & 98.6 & 96.7 \\
\hline Rp3 & Rhinolophus sinicus & China & 95.4 & 99.7 & 99.5 & 99.7 & 99.2 & 97.4 & 98.3 & 97.7 & 80.3 & 100 & 97.3 & 98.1 \\
\hline $\mathrm{Rm} 1$ & Rhinolophus macrotis & China & 91.0 & 99.3 & 99.3 & 99.3 & 97.9 & 97.1 & 98.0 & 95.6 & 80.6 & 98.7 & 97.3 & 97.6 \\
\hline Rf1 & $\begin{array}{l}\text { Rhinolophus } \\
\text { ferrumequinum }\end{array}$ & China & 92.3 & 99.7 & 98.6 & 99.5 & 97.9 & 97.7 & 96.3 & 96.0 & 78.4 & 96.1 & 97.7 & 95.5 \\
\hline Rs672 & Rhinolophus sinicus & China & 97.0 & 99.3 & 99.8 & 99.3 & 99.1 & 98.6 & 99.0 & 98.4 & 80.2 & 100 & 98.6 & 98.6 \\
\hline Rs3367 & Rhinolophus sinicus & China & 97.0 & 100 & 99.6 & 99.8 & 99.2 & 98.3 & 98.0 & 98.4 & 92.3 & 100 & 98.2 & 100 \\
\hline RsSHC014 & Rhinolophus sinicus & China & 96.9 & 99.7 & 99.6 & 99.8 & 99.2 & 98.8 & 97.7 & 98.4 & 90.0 & 98.7 & 98.2 & 99.5 \\
\hline WIV1 & Rhinolophus sinicus & China & 97.0 & 99.7 & 99.5 & 99.8 & 99.2 & 98.8 & 98.0 & 98.4 & 92.2 & 100 & 98.2 & 99.8 \\
\hline Cp/Yunnan 2011 & Chaerephon plicata & China & 97.6 & 100 & 99.1 & 98.5 & 98.1 & 98.6 & 97.3 & 98.2 & 81.1 & 100 & 99.1 & 98.1 \\
\hline Rp/Shaanxi 2011 & Rhinolophus pusillus & China & 93.5 & 100 & 99.2 & 99.7 & 98.9 & 97.7 & 99.0 & 96.9 & 81.1 & 97.4 & 96.8 & 98.1 \\
\hline YNLF_31C & $\begin{array}{l}\text { Rhinolophus } \\
\text { ferrumequinum }\end{array}$ & China & 97.2 & 99.7 & 99.6 & 99.7 & 99.4 & 98.3 & 97.7 & 98.4 & 79.2 & 100 & 98.6 & 98.3 \\
\hline BM48-31 & Rhinolophus blasii & Bulgaria & 76.8 & 94.4 & 98.0 & 98.1 & 95.6 & 91.9 & 91.6 & 88.3 & 75.9 & 92.1 & 91.4 & 88.5 \\
\hline HKU4-1 & Tylonycteris pachypus & China & 55.5 & 81 & 89.8 & 92.1 & 85.4 & 76 & 82.8 & 78.4 & 67 & 56.1 & 79 & 65.8 \\
\hline HKU5-1 & Pipistrellus abramus & China & 56.4 & 82.6 & 91.8 & 93.8 & 91.7 & 79.7 & 85.7 & 80.1 & 64 & 53.6 & 79 & 61.4 \\
\hline NeoCoV & Neoromica capensis & $\begin{array}{l}\text { South } \\
\text { Africa }\end{array}$ & 86.7 & 96.7 & 98 & 98.4 & 98.2 & 94.1 & 96.3 & 95 & 64 & 87.7 & 94.2 & 91 \\
\hline SC2013 & Vespertilio superans & China & 53.5 & 79 & 88.5 & 93.4 & 85.6 & 76.6 & 88.1 & 85.7 & 69 & 84.5 & 84.7 & 74.4 \\
\hline
\end{tabular}

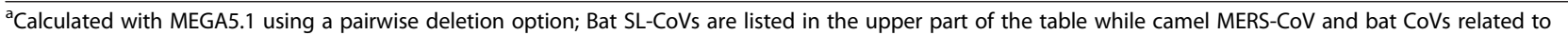
MERS-CoV in the lower part

@Seven domains were series connected and calculated with MEGA5.1 using a pairwise deletion option

ADRP, ADP-ribose 1-phosphatase; 3CLpro, coronavirus NSP5 protease; RdRp RNA-dependent RNA polymerase; Hel, helicase; ExoN, exoribonuclease; NendoU, endoribonuclease; OMT, 2'-O-methyltransferase

GenBank accession numbers: Tor2, NC_004718; HKU3, DQ022305; Rp3, DQ071615; Rm1, DQ412043; Rf1, DQ412042; Rs672, FJ588686; Rs3367, KC881006; RsSHC014, KC881005; WIV1, KF367457; Cp/Yunnan2011, JX993988; Rp/Shaanxi2011, JX993987; YNLF_31C, KP886808; EMC/2012, JX869059; HKU5-1, NC_009020; HKU4-1, NC_009019; BetaCoV/SC2013, KJ473821; NeoCoV, KC869678 
In 2005, a breakthrough was made as two independent research groups reported, almost simultaneously, the discovery of novel coronaviruses related to SARS-CoV in horseshoe bats (in the genus Rhinolophus) in China, which were termed SARS-like coronavirus (SL-CoV) $[48,49]$. These bat SL-CoVs from both mainland China and Hong Kong manifested genome sequence identity of 88-90\% among themselves and 87-92 \% identity to human or civet SARS-CoV isolates. The unique set of ORFs exclusively found in SARS-CoV was also present in bat SL-CoVs, demonstrating the close phylogenetic relationship between SARS-CoV and SL-CoV. The discovery of bat SL-CoV boosted researchers' interest in coronavirus surveillance studies in bats. In following years, SL-CoV RNA was detected in Rhinolophus species of a wider geographic range in China. The provinces or regions where SL-CoV-positive bats were captured included Hong Kong, Guangxi, Hubei, Shandong, Guizhou, Shaanxi and Yunnan [50-53]. 7 conserved replicase domains in orflab of these SL-CoVs found in China were compared with those of SARS-CoV (Table 1). They all shared higher than $95 \%$ aa sequence identity with SARS$\mathrm{CoV}$ in the concatenated domains and therefore can be considered to belong to SARS-CoV species [54].

SL-CoVs were also discovered in rhinolophids from Slovenia, Bulgaria and Italy in Europe [55-57]. These European SL-CoVs exhibited significant genetic variation from Chinese isolates. The strain BM48-31 from Rhinolophus blasii in Bulgaria was highly divergent from Chinese isolates, displaying major sequence differences in several genes including ORF3b and ORF6 and lacking the coding region of ORF8 in its genome [55]. In Africa, novel betacoronaviruses related to SARS-CoV have been detected in Hipposideros and Chaerophon species from Ghana, Kenya and Nigeria. However, compared with Asian and European SL-CoVs, these viruses of non-rhinolophid origin were phylogenetically distant to SARS-CoV. The Western African isolates even formed a potential new lineage of Betacoronavirus in the phylogenetic tree (Fig. 1a) [58-60].

\section{Most related ancestor of SARS-CoV in bats}

Although the aforementioned bat SL-CoVs showed high sequence identity to SARS-CoV, two deletions were present in the RBM of their S proteins $[48,49]$. The differences in RBM substantially changed the receptor usage. In a study using an HIV-based pseudovirus system and cell lines expressing human, civet, and horseshoe bat ACE2 molecules, the bat SL-CoV Rp3 S protein demonstrated its inability to use ACE2 as cell receptor [61]. However, the chimeric Rp3 S protein carrying the RBD of SARS-CoV S protein was conferred the capability of cell entry via human ACE2 [61]. These results suggested that bat SL-CoVs such as Rp3 were unlikely to cause human infection. Therefore, they may not be considered as the direct progenitor of SARS-CoV. Besides, the theory of bat origin of SARS-CoV lacked a powerful support due to the failure of direct isolation of SL-CoV from bats, despite numerous trials by our group as well as many others around the world.

During our longitudinal surveillance at a Rhinolophus sinicus colony in Yunnan Province over the years, a major breakthrough came in 2013 when diverse SLCoVs were discovered in the single colony [53]. In this colony, there were at least 7 different strains related to SARS-CoV, HKU3, Rs672 or Rf1, based on analysis of the region corresponding to SARS-CoV RBD. Intriguingly, unlike all previously described SL-CoVs, two strains, designated Rs3367 and RsSHC014, did not contain the deletions in this region. Rs3367 showed a particularly high sequence identity to SARS-CoV in RBD and was identical to SARS-CoV in several key amino acid residues known to be important for receptor binding [53]. Whole genome sequencing revealed that Rs3367 and RsSHC014 shared more than $95 \%$ genome sequence identity with human and civet SARS-CoV, which was remarkably higher than that of any other bat SL-CoV (76 to $92 \%$ ). Regarding individual genes, the amino acid sequence identity between Rs3367 or RsSHC014 and SARS-CoV was higher than $96 \%$ in ORF1a, 1b, 3a, 3b, E, M and N genes [53]. Most importantly, a live SL-CoV was isolated for the first time from bat fecal samples [53]. This virus, termed WIV1, had almost identical sequence (99.9 \%) to Rs3367 and was demonstrated to use ACE2 molecules from humans, civets and Chinese horseshoe bats for cell entry. It also displayed infectivity in cell lines from a broad range of species including human, pig, and bat. Furthermore, the close relatedness between WIV1 and SARS-CoV was confirmed by neutralization effect of convalescent SARS patient sera on WIV1 [53]. The isolation of a bat SL$\mathrm{CoV}$ genetically closely resembling SARS-CoV and having a functional $S$ protein capable of using the same ACE2 receptor as SARS-CoV provided robust and conclusive evidence for the bat origin of SARS-CoV.

\section{Possible origin of SARS-CoV from recombination of different SL-CoVs}

Despite the fact that Rs3367 or WIV1 is unprecedently close to SARS-CoV in terms of RBD region and genome identity, still there are gaps between them and the immediate ancestor of SARS-CoV. ORF8 is a highly variable gene and remarkable differences can be observed among SARS-CoVs and SL-CoVs of different host origins. Isolates from civets and from early phase of the 2002/2003 pandemic contained a single long ORF8, while in the human SARS-CoV isolates from the middle and late phase of the pandemic the ORF8 was disrupted 
into two ORFs, ORF8a and ORF8b, as a result of the acquisition of a 29-nt deletion after interspecies transmission to humans $[8,40,62]$. The SL-CoVs from Rhinolophus sinicus, including Rs3367, however, had a single ORF8 with only $32-33 \%$ amino acid identities to that of civet SARS-CoV. In contrast, the ORF8 of two novel SL-CoV strains recently reported in Yunnan from another rhinolophid species, Rhinolophus ferrumequinum, exhibited exceptionally high (81.3 \%) amino acid identity to civet SARS-CoV SZ3 [63]. This is consistent with isolate Rf1, a SL-CoV reported earlier from $R$. ferrumequinum in Hubei Province, of which the ORF8 shared $80.4 \%$ amino acid identity to SZ3 [48]. Potential recombination sites were identified around the ORF8 region between SLCoVs from R.sinicus and R.ferrumequinum and it has been suggested that the ancestor of civet SARS-CoV probably acquired ORF8 from R.ferrumequinum SLCoVs by recombination [63].

\section{Animal origins of MERS-CoV}

As with SARS-CoV, most early MERS cases had contact history with animals, e.g., dromedary camels [64, 65]. MERS-CoV RNA was detected in camels from Saudi Arabia, Qatar and Egypt and showed high similarities (>99 \%) to human MERS-CoV in genomic sequences [66-71]. Serological evidence further confirmed a high prevalence of MERS-CoV infections in camels in the Middle East [72-77], Africa [78-80] and Europe (Spain) [73]. The neutralization antibodies in camels could be traced back to 1983 [73, 80]. These results strongly suggested that MERS-CoV infection in humans were transmitted through close contact with infected camels $[66,76,81-83]$.

\section{Bat viruses related to MERS-CoV}

Prior to the emergence of MERS-CoV, a group of bat coronaviruses had been reported including Tylonycteris bat coronavirus HKU4 (BtCoV-HKU4) in Tylonycteris bats and Pipistrellus bat coronavirus HKU5 (BtCoVHKU5) in Pipistrellus bats in China [50, 84, 85], E.isa/ M/Spain/2007 in Eptesicus isabellinus bats in Spain [86] and N.noc/VM366/2008/NLD in Pipistrellus pipistrellus bats in the Netherlands [87]. Based on genomic sequence analysis, these bat coronaviruses were grouped into lineage $\mathrm{C}$ of the genus Betacoronavirus. After the outbreak of MERS, MERS-CoV related coronaviruses were found in more bat species and countries [88-96]. Among these viruses, full-length or near full-length genomes of BtCoV-HKU4, BtCoV-HKU5, SC2013 and $\mathrm{NeoCoV}$ have been characterized. By genomic analysis of lineage $\mathrm{C}$ betacoronaviruses, MERS-CoV derived from camels show high similarities to human MERS-CoV with $>99.5 \%$ nt identities, confirming that the human and camel isolates belong to the same coronavirus species.
Bat HKU4, HKU5, NeoCoV and SC2013, shared 69.8, 70, 85.6 and $75.6 \%$ nt identities with MERS-CoV at genomic level, respectively. Seven conserved replicase domains in orf1ab of MERS-CoV related viruses were compared with MERS-CoV (Table 1). The concatenated translated domains of $\mathrm{NeoCoV}$ shared $95 \%$ aa sequence identity with MERS-CoV and it could be classified as the same MERS-CoV species [54]. Other bat coronaviruses, HKU4, HKU5 and SC2013, could be considered as different coronavirus species. The most recent ancestor analysis speculated that MERS-CoV may have jumped from bats to camels approximately 20 years ago in Africa, with camels then being imported into the Arabian Peninsula [92], while HKU5 and MERS-CoV may have diverged from their common ancestor about 400 to 500 years ago [85].

Although NeoCoV is closer to MERS-CoV than other bat coronaviruses at genomic level, the phylogenetic analysis of the spike protein showed that HKU4 is the most closely related to MERS-CoV among all currently known bat coronaviruses, sharing $67 \%$ sequence identity (Fig. 1b). This is correlated with the capability of HKU4 of using DPP4 as its functional receptor. However, HKU4 preferred bat DPP4 over human DPP4, whereas MERS-CoV showed the opposite trend [97]. It was suggested that MERS-CoV ancestors had been circulating in bats for very long time. MERS-CoV has evolved to adapt to use human receptor and the DPP4-recognizing bat coronaviruses like HKU4 may follow up, thereby posing a serious risk to human health $[97,98]$.

\section{Comparison of transmission of MERS-CoV and SARS-CoV}

Both SARS-CoV and MERS-CoV are emerging zoonotic pathogens that crossed the species barriers to infect humans [10, 53, 99]. Evidence showed that SARS-CoV and MERS-CoV originated from bats, the nature reservoirs, then transmitted to human via intermediate hosts civets and camels, respectively [10, 40, 53, 81, 100]. Human SARS-CoV infection originated from the direct contact between humans and civets in markets or restaurants. Closing wet markets and cleaning civet cut off the spread chain of SARS-CoV and effectively ended the SARS epidemic $[40,42,101]$. In contrast, MERS-CoV is believed to have existed in camels for a very long time and camels are widely distributed in Middle East and African countries, serving as important transport vectors and sources of meat and milk for the local population. Therefore, it is difficult to adopt the same strategy of SARS-CoV control in the prevention of future MERS$\mathrm{CoV}$ outbreaks. Until a comprehensive approach is found, which most likely will involve the effective vaccination of camels against MERS-CoV among other measures, it is envisaged that sporadic human infection will persist for some time in the future $[11,70]$. 
Bat coronaviruses and human coronavirus 229E (HCoV-229E) and NL63 (HCoV-NL63)

$\mathrm{HCoV}-229 \mathrm{E}$ was found in the 1960s and causes comparatively mild common colds worldwide [102]. A bat coronavirus detected in Hipposideros caffer ruber in Ghana termed Hipposideros/GhanaKwam/19/2008 was genetically related to $\mathrm{HCoV}-229 \mathrm{E}$. Its $\mathrm{RdRp}$ fragment shared $92 \%$ nucleotide sequence identity with $\mathrm{HCoV}$ $229 \mathrm{E}$ and they were predicted to share a most recent common ancestor (MRCA) only 200 years ago [58]. A recent study characterized more 229E-related coronaviruses discovered in hipposiderid bats from Ghana on full genome level. These bat coronaviruses were more diversified and formed a single viral species with $\mathrm{HCoV}$ 229E. Interestingly, phylogenetic analysis revealed the intermediate position of a 229E-related alpaca virus between bat and human viruses. These findings suggested the ancestral origin of $\mathrm{HCoV}-229 \mathrm{E}$ in hipposiderid bats and the role of camelids as potential intermediate hosts was hypothesized [103].

HCoV-NL63 was first isolated from babies suffering of pneumonia and bronchiolitis in 2004 [104]. To date, HCoV-NL63 has been found worldwide with up to $9.3 \%$ detection rate in hospitalized respiratory tract samples [105]. In 2010, a bat coronavirus termed ARCoV.2 (Appalachian Ridge CoV) detected in North American tricolored bat (Perimyotis subflavus) in the US showed close relationship with HCoV-NL63. The MRCA for HCoV-NL63 and ARCoV.2 was predicted to have existed 563 to 822 years ago [106, 107]. Further analysis indicated that $\mathrm{HCoV}-\mathrm{NL} 63$ can replicate in cell lines derived from the lungs of tricolored bats [107]. These results suggest that prototypes of $\mathrm{HCoV}$ NL63 may also exist in bats and there may also be a bat origin of this human coronavirus.

\section{Conclusions}

Although the study of bat-borne coronaviruses has only started just about 10 years ago, the scientific community has already learnt a great deal of useful lessons which will be instrumental in mitigating, predicting, and preventing future zoonotic coronavirus outbreaks. Some of these lessons are summarized below.

Bats harbor coronaviruses with great genetic diversity. It is believed that most, if not all, currently circulating alphacoronaviruses and betacoronaviruses in different mammals are evolutionally linked to ancestral coronaviruses originated from bats. Different species of rhinolophid bats in China carry genetically diverse SARS-like coronaviruses, some of which are direct ancestors of SARS-CoV and hence have the potential to cause direct interspecies transmission to humans. Meanwhile, different coronavirus species closely related to MERS-CoV are circulating in bats. Bats are likely natural reservoirs of MERS-CoV or an ancestral MERS-like CoV. It is hypothesized that bat MERS-like $\mathrm{CoV}$ jumped to camels or some other as yet unidentified animal several decades ago. The virus evolved and adapted with accumulating mutations in camels and then was transmitted to humans very recently. It took almost a decade from the first discovery of SL-CoV in bats to the final isolation of the SARS-CoV ancestral virus from bats, so continuing surveillance is vital to uncover the origin of MERS-CoV and bats should certainly be a priority of research. Besides, as the spike protein and host receptor are key factors of cross-species transmission of coronaviruses, characterization of the receptor and key binding sites of the spike protein will be important in estimating host tropism of bat coronaviruses and predicting spillover risk.

With human activity increasingly overlapping the habitats of bats, diseases outbreaks resulted from spillover of bat coronaviruses will continue to occur in the future despite the fact that direct transmission of bat coronaviruses to humans appears to be rare. To better prepare ourselves in predicting and preventing the next emergence of a coronavirus disease, it is necessary to maintain our vigilance in long-term coronavirus surveillance studies in bats as well as in other wildlife and livestock. Combined with other laboratory-based studies such as receptor specificity, pathogenesis and animal infection, a focus on continued surveillance will help us to improve risk assessment as well as to reveal the potential intermediate hosts that may play an important role in the interspecies transmission of various known and as yet unknown bat coronaviruses.

\section{Abbreviations}

SARS: Severe acute respiratory syndrome; MERS: Middle East respiratory syndrome; SARS-CoV: Severe acute respiratory syndrome coronavirus; MERS-CoV: Middle East respiratory syndrome coronavirus; ORF: Open reading frame; ACE2: Angiotensin-converting enzyme 2; RBD: Receptor-binding domain; RBM: Receptor-binding motif; DPP4: Dipeptidyl peptidase 4; SL-CoV: SARS-like coronavirus; MRCA: Most recent common ancestor.

\section{Competing interests}

The authors declare that they have no competing interests.

\section{Authors' contributions}

ZS developed the structural design of the review. $\mathrm{BH}$ and $\mathrm{XG}$ drafted the manuscript. LFW was involved in revising the manuscript. All authors read and approved the final manuscript.

\section{Acknowledgements}

This work was jointly funded by National Natural Science Foundation of China (81290341), Scientific and technological basis special project from the Minister of Science and Technology of the People's Republic of China (2013FY113500), and the National Institutes of Health (NIAID R01Al110964).

\section{Author details}

${ }^{1}$ Key Laboratory of Special Pathogens and Center for Emerging Infectious Diseases, Wuhan Institute of Virology, Chinese Academy of Sciences, Wuhan, China. ${ }^{2}$ Program in Emerging Infectious Diseases, Duke-NUS Graduate Medical School, Singapore 169857, Singapore. 
Received: 16 September 2015 Accepted: 11 November 2015 Published online: 22 December 2015

\section{References}

1. Smith I, Wang LF. Bats and their virome: An important source of emerging viruses capable of infecting humans. Curr Opin Virol. 2013;3(1):84-91. doi:10.1016/j.coviro.2012.11.006

2. Shi Z. Emerging infectious diseases associated with bat viruses. Sci China Life Sci. 2013;56(8):678-82. doi:10.1007/s11427-013-4517-x.

3. Drexler JF, Corman VM, Drosten C. Ecology, evolution and classification of bat coronaviruses in the aftermath of SARS. Antiviral Res. 2014;101:45-56. doi:10.1016/j.antiviral.2013.10.013.

4. de Groot R, Baker S, Baric R, Enjuanes L, Gorbalenya A, Holmes K, et al. Family Coronaviridae. In: King A, Adams M, Cartens E, Lefkowitz E, editors. Virus Taxonomy; Ninth Report of the International Committee on Taxonomy of Viruses. San Diego: Academic; 2012. p. 806-28.

5. Woo PC, Lau SK, Lam CS, Lau CC, Tsang AK, Lau JH, et al. Discovery of seven novel Mammalian and avian coronaviruses in the genus deltacoronavirus supports bat coronaviruses as the gene source of alphacoronavirus and betacoronavirus and avian coronaviruses as the gene source of gammacoronavirus and deltacoronavirus. J Virol. 2012;86(7):3995-4008. doi:10.1128/JVI.06540-11.

6. Zhong NS, Zheng BJ, Li YM, Poon, Xie ZH, Chan KH, et al. Epidemiology and cause of severe acute respiratory syndrome (SARS) in Guangdong, People's Republic of China, in February, 2003. Lancet. 2003;362(9393):1353-8.

7. Chinese SARS Molecular Epidemiology Consortium. Molecular evolution of the SARS coronavirus during the course of the SARS epidemic in China. Science. 2004;303(5664):1666-9. doi:10.1126/science.1092002.

8. Song HD, Tu CC, Zhang GW, Wang SY, Zheng K, Lei LC, et al. Cross-host evolution of severe acute respiratory syndrome coronavirus in palm civet and human. Proc Natl Acad Sci U S A. 2005;102(7):2430-5. doi:10.1073/pnas.0409608102.

9. Bermingham A, Chand MA, Brown CS, Aarons E, Tong C, Langrish C, et al. Severe respiratory illness caused by a novel coronavirus, in a patient transferred to the United Kingdom from the Middle East, September 2012. Euro Surveill. 2012;17(40):20290.

10. Zaki AM, van Boheemen S, Bestebroer TM, Osterhaus AD, Fouchier RA. Isolation of a novel coronavirus from a man with pneumonia in Saudi Arabia. N Engl J Med. 2012;367(19):1814-20. doi:10.1056/NEJMoa1211721.

11. WHO. Summary and risk assessment of current situation in Republic of Korea and China. 2015(http://www.who.int/csr/disease/coronavirus_ infections/risk-assessment-19june2015/en/)

12. Korean Society of Infectious D, Korean Society for Healthcare-associated Infection C, Korean Society for Healthcare-associated Infection C, Prevention. An unexpected outbreak of middle east respiratory syndrome coronavirus infection in the Republic of Korea, 2015. Infect Chemother. 2015;47(2):120-2. doi:10.3947/ic.2015.47.2.120.

13. Rota PA, Oberste MS, Monroe SS, Nix WA, Campagnoli R, Icenogle JP, et al. Characterization of a novel coronavirus associated with severe acute respiratory syndrome. Science. 2003;300(5624):1394-9. doi:10.1126/science.1085952.

14. Marra MA, Jones SJ, Astell CR, Holt RA, Brooks-Wilson A, Butterfield YS, et al. The genome sequence of the SARS-associated coronavirus. Science. 2003; 300(5624):1399-404. doi:10.1126/science.1085953.

15. Snijder EJ, Bredenbeek PJ, Dobbe JC, Thiel V, Ziebuhr J, Poon LL, et al. Unique and conserved features of genome and proteome of SARScoronavirus, an early split-off from the coronavirus group 2 lineage. J Mol Biol. 2003;331(5):991-1004.

16. Woo PC, Lau SK, Li KS, Tsang AK, Yuen KY. Genetic relatedness of the novel human group C betacoronavirus to Tylonycteris bat coronavirus HKU4 and Pipistrellus bat coronavirus HKU5. Emerg Microbes Infect. 2012;1(11):e35. doi:10.1038/emi.2012.45.

17. van Boheemen S, de Graaf M, Lauber C, Bestebroer TM, Raj VS, Zaki AM et al. Genomic characterization of a newly discovered coronavirus associated with acute respiratory distress syndrome in humans. MBio. 2012;3(6). doi:10. 1128/mBio.00473-12.

18. de Groot RJ, Baker SC, Baric RS, Brown CS, Drosten C, Enjuanes L, et al. Middle East respiratory syndrome coronavirus (MERS-CoV): Announcement of the Coronavirus Study Group. J Virol. 2013;87(14): 7790-2. doi:10.1128/JVl.01244-13.
19. Zaki AM. Novel coronavirus—Saudi Arabia: Human isolate. Int Soc Infect Dis. 2012;2012-09-20.(ProMED-mail.).

20. Masters PS. The molecular biology of coronaviruses. Adv Virus Res. 2006;66: 193-292. doi:10.1016/S0065-3527(06)66005-3.

21. Gallagher TM, Buchmeier MJ. Coronavirus spike proteins in viral entry and pathogenesis. Virology. 2001;279(2):371-4. doi:10.1006/viro.2000.0757.

22. Li W, Moore MJ, Vasilieva N, Sui J, Wong SK, Berne MA, et al. Angiotensinconverting enzyme 2 is a functional receptor for the SARS coronavirus. Nature. 2003:426(6965):450-4. doi:10.1038/nature02145.

23. Hamming I, Timens W, Bulthuis ML, Lely AT, Navis G, van Goor H. Tissue distribution of ACE2 protein, the functional receptor for SARS coronavirus. A first step in understanding SARS pathogenesis. J Pathol. 2004;203(2):631-7. doi:10.1002/path.1570.

24. Ding Y, He L, Zhang Q, Huang Z, Che X, Hou J, et al. Organ distribution of severe acute respiratory syndrome (SARS) associated coronavirus (SARS-CoV) in SARS patients: Implications for pathogenesis and virus transmission pathways. J Pathol. 2004;203(2):622-30. doi:10.1002/path.1560.

25. Wong SK, Li W, Moore MJ, Choe H, Farzan M. A 193-amino acid fragment of the SARS coronavirus $S$ protein efficiently binds angiotensin-converting enzyme 2. J Biol Chem. 2004;279(5):3197-201. doi:10.1074/jbc.C300520200.

26. Li F, Li W, Farzan M, Harrison SC. Structure of SARS coronavirus spike receptor-binding domain complexed with receptor. Science. 2005;309(5742): 1864-8. doi:10.1126/science.1116480.

27. Qu XX, Hao P, Song XJ, Jiang SM, Liu YX, Wang PG, et al. Identification of two critical amino acid residues of the severe acute respiratory syndrome coronavirus spike protein for its variation in zoonotic tropism transition via a double substitution strategy. J Biol Chem. 2005;280(33):29588-95. doi:10.1074/jbc.M500662200.

28. Li W, Zhang C, Sui J, Kuhn JH, Moore MJ, Luo S, et al. Receptor and viral determinants of SARS-coronavirus adaptation to human ACE2. EMBO J. 2005;24(8):1634-43. doi:10.1038/sj.emboj.7600640.

29. Raj VS, Mou H, Smits SL, Dekkers DH, Muller MA, Dijkman R, et al. Dipeptidyl peptidase 4 is a functional receptor for the emerging human coronavirusEMC. Nature. 2013:495(7440):251-4. doi:10.1038/nature12005.

30. Barlan A, Zhao J, Sarkar MK, Li K, McCray Jr PB, Perlman S, et al. Receptor variation and susceptibility to Middle East respiratory syndrome coronavirus infection. J Virol. 2014;88(9):4953-61. doi:10.1128/JVI.00161-14.

31. de Wit E, Prescott J, Baseler L, Bushmaker T, Thomas T, Lackemeyer MG, et al. The Middle East respiratory syndrome coronavirus (MERS-CoV) does not replicate in Syrian hamsters. PLoS One. 2013;8(7):e69127. doi:10.1371/journal.pone.0069127.

32. Coleman CM, Matthews KL, Goicochea L, Frieman MB. Wild-type and innate immune-deficient mice are not susceptible to the Middle East respiratory syndrome coronavirus. J Gen Virol. 2014;95(Pt 2):408-12. doi:10.1099/vir.0.060640-0.

33. Eckerle I, Corman VM, Muller MA, Lenk M, Ulrich RG, Drosten C. Replicative capacity of MERS coronavirus in livestock cell lines. Emerg Infect Dis. 2014; 20(2):276-9. doi:10.3201/eid2002.131182.

34. Chan JF, Chan KH, Choi GK, To KK, Tse H, Cai JP, et al. Differential cell line susceptibility to the emerging novel human betacoronavirus 2C EMC/2012: Implications for disease pathogenesis and clinical manifestation. J Infect Dis. 2013;207(11):1743-52. doi:10.1093/infdis/jit123.

35. van Doremalen N, Miazgowicz KL, Milne-Price S, Bushmaker T, Robertson S, Scott D et al. Host Species Restriction of Middle East Respiratory Syndrome Coronavirus through its Receptor Dipeptidyl Peptidase 4. J Virol. 2014. doi: 10.1128/JVl.00676-14.

36. Haagmans BL, van den Brand JM, Provacia LB, Raj VS, Stittelaar KJ, Getu S, et al. Asymptomatic Middle East respiratory syndrome coronavirus infection in rabbits. J Virol. 2015;89(11):6131-5. doi:10.1128/JVI.00661-15.

37. Lu G, Hu Y, Wang Q, Qi J, Gao F, Li Y, et al. Molecular basis of binding between novel human coronavirus MERS-CoV and its receptor CD26. Nature. 2013;500(7461):227-31. doi:10.1038/nature12328.

38. Wang N, Shi $X$, Jiang L, Zhang S, Wang D, Tong P, et al. Structure of MERSCoV spike receptor-binding domain complexed with human receptor DPP4. Cell Res. 2013;23(8):986-93. doi:10.1038/cr.2013.92.

39. Chen $Y$, Rajashankar KR, Yang Y, Agnihothram SS, Liu C, Lin YL, et al. Crystal structure of the receptor-binding domain from newly emerged Middle East respiratory syndrome coronavirus. J Virol. 2013;87(19):10777-83. doi:10.1128/JVI.01756-13.

40. Guan $Y$, Zheng BJ, He YQ, Liu XL, Zhuang ZX, Cheung $C L$, et al. Isolation and characterization of viruses related to the SARS coronavirus from animals 
in southern China. Science. 2003;302(5643):276-8. doi:10.1126/science. 1087139.

41. Centers for Disease C, Prevention. Prevalence of IgG antibody to SARSassociated coronavirus in animal traders-Guangdong Province, China, 2003. MMWR Morb Mortal Wkly Rep. 2003;52(41):986-7.

42. Xu HF, Wang M, Zhang ZB, Zou XZ, Gao Y, Liu XN, et al. An epidemiologic investigation on infection with severe acute respiratory syndrome coronavirus in wild animals traders in Guangzhou. Zhonghua yu fang yi xue za zhi. 2004;38(2):81-3.

43. Kan $B$, Wang $M$, Jing $H, X u H$, Jiang $X$, Yan $M$, et al. Molecular evolution analysis and geographic investigation of severe acute respiratory syndrome coronavirus-like virus in palm civets at an animal market and on farms. J Virol. 2005;79(18):11892-900. doi:10.1128/JVI.79. 18.11892-11900.2005.

44. Poon LL, Chu DK, Chan KH, Wong OK, Ellis TM, Leung YH, et al. Identification of a novel coronavirus in bats. J Virol. 2005;79(4):2001-9. doi:10.1128/JVI.79.4.2001-2009.2005.

45. Wu D, Tu C, Xin C, Xuan H, Meng Q, Liu Y, et al. Civets are equally susceptible to experimental infection by two different severe acute respiratory syndrome coronavirus isolates. J Virol. 2005;79(4):2620-5. doi:10.1128/JVI.79.4.2620-2625.2005.

46. Halpin K, Young PL, Field HE, Mackenzie JS. Isolation of Hendra virus from pteropid bats: A natural reservoir of Hendra virus. J Gen Virol. 2000;81(Pt 8): 1927-32.

47. Yob JM, Field H, Rashdi AM, Morrissy C, van der Heide B, Rota P, et al. Nipah virus infection in bats (order Chiroptera) in peninsular Malaysia. Emerg Infect Dis. 2001;7(3):439-41.

doi:10.3201/eid0703.010312.

48. Li W, Shi Z, Yu M, Ren W, Smith C, Epstein JH, et al. Bats are natural reservoirs of SARS-like coronaviruses. Science. 2005;310(5748):676-9. doi:10.1126/science.1118391.

49. Lau SK, Woo PC, Li KS, Huang Y, Tsoi HW, Wong BH, et al. Severe acute respiratory syndrome coronavirus-like virus in Chinese horseshoe bats. Proc Natl Acad Sci U S A. 2005;102(39):14040-5. doi:10.1073/pnas.0506735102.

50. Tang XC, Zhang JX, Zhang SY, Wang P, Fan XH, Li LF, et al. Prevalence and genetic diversity of coronaviruses in bats from China. J Virol. 2006;80(15): 7481-90. doi:10.1128/JVI.00697-06.

51. Woo PC, Lau SK, Li KS, Poon RW, Wong BH, Tsoi HW, et al. Molecular diversity of coronaviruses in bats. Virology. 2006;351(1):180-7. doi:10.1016/j.virol.2006.02.041

52. Yuan J, Hon CC, Li Y, Wang D, Xu G, Zhang H, et al. Intraspecies diversity of SARS-like coronaviruses in Rhinolophus sinicus and its implications for the origin of SARS coronaviruses in humans. J Gen Virol. 2010;91(Pt 4):1058-62. doi:10.1099/vir.0.016378-0.

53. Ge XY, Li JL, Yang XL, Chmura AA, Zhu G, Epstein JH, et al. Isolation and characterization of a bat SARS-like coronavirus that uses the ACE2 receptor. Nature. 2013;503(7477):535-8. doi:10.1038/nature12711.

54. King AMQ, Adams MJ, Carstens EB, Lefkowitz EJ. Virus taxonomy: Classification and nomenclature of viruses: Ninth Report of the International Committee on Taxonomy of Viruses. San Diego: Elsevier; 2012.

55. Drexler JF, Gloza-Rausch F, Glende J, Corman VM, Muth D, Goettsche M, et al. Genomic characterization of severe acute respiratory syndrome-related coronavirus in European bats and classification of coronaviruses based on partial RNA-dependent RNA polymerase gene sequences. J Virol. 2010; 84(21):11336-49. doi:10.1128/JVI.00650-10.

56. Rihtaric D, Hostnik P, Steyer A, Grom J, Toplak I. Identification of SARS-like coronaviruses in horseshoe bats (Rhinolophus hipposideros) in Slovenia. Arch Virol. 2010;155(4):507-14. doi:10.1007/s00705-010-0612-5.

57. Balboni A, Palladini A, Bogliani G, Battilani M. Detection of a virus related to betacoronaviruses in Italian greater horseshoe bats. Epidemiol Infect. 2011; 139(2):216-9. doi:10.1017/S0950268810001147.

58. Pfefferle S, Oppong S, Drexler JF, Gloza-Rausch F, Ipsen A, Seebens A, et al. Distant relatives of severe acute respiratory syndrome coronavirus and close relatives of human coronavirus $229 \mathrm{E}$ in bats. Ghana Emerg Infect Dis. 2009; 15(9):1377-84. doi:10.3201/eid1509.090224.

59. Tong S, Conrardy C, Ruone S, Kuzmin IV, Guo X, Tao Y, et al. Detection of novel SARS-like and other coronaviruses in bats from Kenya. Emerg Infecti Dis. 2009;15(3):482-5. doi:10.3201/eid1503.081013.

60. Quan PL, Firth C, Street C, Henriquez JA, Petrosov A, Tashmukhamedova A et al. Identification of a severe acute respiratory syndrome coronavirus-like virus in a leaf-nosed bat in Nigeria. MBio. 2010;1 (4). doi:10.1128/mBio.00208-10.
61. Ren W, Qu X, Li W, Han Z, Yu M, Zhou P, et al. Difference in receptor usage between severe acute respiratory syndrome (SARS) coronavirus and SARSlike coronavirus of bat origin. J Virol. 2008;82(4):1899-907. doi:10.1128/JVI.01085-07.

62. Oostra M, de Haan CA, Rottier PJ. The 29-nucleotide deletion present in human but not in animal severe acute respiratory syndrome coronaviruses disrupts the functional expression of open reading frame 8. J Virol. 2007; 81(24):13876-88. doi:10.1128/JVI.01631-07.

63. Lau SK, Feng Y, Chen H, Luk HK, Yang WH, Li KS, et al. Severe Acute Respiratory Syndrome (SARS) coronavirus ORF8 protein is acquired from SARS-related coronavirus from greater horseshoe bats through recombination. J Virol. 2015:89(20):10532-47. doi:10.1128/JVI.01048-15.

64. Albarrak AM, Stephens GM, Hewson R, Memish ZA. Recovery from severe novel coronavirus infection. Saudi Med J. 2012;33(12):1265-9.

65. Health Protection Agency (HPA) UK Novel Coronavirus Investigation team. Evidence of person-to-person transmission within a family cluster of novel coronavirus infections, United Kingdom, February 2013. Euro Surveill. 2013; 18:20427.

66. Memish ZA, Cotten M, Meyer B, Watson SJ, Alsahafi AJ, Al Rabeeah AA, et al. Human infection with MERS coronavirus after exposure to infected camels, Saudi Arabia, 2013. Emerg Infect Dis. 2014;20(6):1012-5. doi:10.3201/eid2006.140402.

67. Chu DK, Poon LL, Gomaa MM, Shehata MM, Perera RA, Abu Zeid D, et al. MERS coronaviruses in dromedary camels. Egypt Emerg Infect Dis. 2014; 20(6):1049-53. doi:10.3201/eid2006.140299.

68. Haagmans BL, Al Dhahiry SH, Reusken CB, Raj VS, Galiano M, Myers R, et al. Middle East respiratory syndrome coronavirus in dromedary camels: An outbreak investigation. Lancet Infect Dis. 2014;14(2):140-5. doi:10.1016/S1473-3099(13)70690-X.

69. Briese T, Mishra N, Jain K, Zalmout IS, Jabado OJ, Karesh WB, et al. Middle East respiratory syndrome coronavirus quasispecies that include homologues of human isolates revealed through whole-genome analysis and virus cultured from dromedary camels in Saudi Arabia. MBio. 2014;5(3): e01146-14. doi:10.1128/mBio.01146-14.

70. Yusof MF, Eltahir YM, Serhan WS, Hashem FM, Elsayed EA, Marzoug BA, et al. Prevalence of Middle East respiratory syndrome coronavirus (MERS-CoV) in dromedary camels in Abu Dhabi Emirate. United Arab Emirates Virus genes. 2015;50(3):509-13. doi:10.1007/s11262-015-1174-0.

71. Annan A, Owusu M, Marfo KS, Larbi R, Sarpong FN, Adu-Sarkodie Y, et al. High prevalence of common respiratory viruses and no evidence of Middle East respiratory syndrome coronavirus in Hajj pilgrims returning to Ghana, 2013. Trop Med Int Health. 2015;20(6):807-12. doi:10.1111/tmi.12482

72. Hemida MG, Perera RA, Wang P, Alhammadi MA, Siu LY, Li M, et al. Middle East Respiratory Syndrome (MERS) coronavirus seroprevalence in domestic livestock in Saudi Arabia, 2010 to 2013. Euro Surveill. 2013;18(50):20659.

73. Reusken CB, Haagmans BL, Muller MA, Gutierrez C, Godeke GJ, Meyer B, et al. Middle East respiratory syndrome coronavirus neutralising serum antibodies in dromedary camels: A comparative serological study. Lancet Infect Dis. 2013;13(10):859-66. doi:10.1016/S1473-3099(13)70164-6.

74. Meyer B, Muller MA, Corman VM, Reusken CB, Ritz D, Godeke GJ, et al. Antibodies against MERS Coronavirus in dromedary camels, United Arab Emirates, 2003 and 2013. Emerg Infect Dis. 2014;20(4):552-9. doi:10.3201/eid2004.131746.

75. Nowotny N, Kolodziejek J. Middle East respiratory syndrome coronavirus (MERS-CoV) in dromedary camels, Oman, 2013. Euro Surveill. 2014;19(16); 20781.

76. Alagaili AN, Briese T, Mishra N, Kapoor V, Sameroff SC, de Wit E, et al. Middle East respiratory syndrome coronavirus infection in dromedary camels in saudi arabia. MBio. 2014;5(2):e00884-14. doi:10.1128/mBio.00884-14.

77. Reusken CB, Ababneh M, Raj VS, Meyer B, Eljarah A, Abutarbush S, et al. Middle East Respiratory Syndrome coronavirus (MERS-CoV) serology in major livestock species in an affected region in Jordan, June to September 2013. Euro Surveill. 2013;18(50):20662.

78. Corman VM, Jores J, Meyer B, Younan M, Liljander A, Said MY, et al. Antibodies against MERS coronavirus in dromedary camels, Kenya, 1992-2013. Emerg Infect Dis. 2014;20(8):1319-22. doi:10.3201/eid2008.140596.

79. Reusken CB, Messadi L, Feyisa A, Ularamu H, Godeke GJ, Danmarwa A, et al. Geographic distribution of MERS coronavirus among dromedary camels. Africa Emerg Infect Dis. 2014;20(8):1370-4. doi:10.3201/eid2008.140590. 
80. Muller MA, Corman VM, Jores J, Meyer B, Younan M, Liljander A, et al. MERS coronavirus neutralizing antibodies in camels, Eastern Africa, 1983-1997. Emerg Infect Dis. 2014;20(12):2093-5. doi:10.3201/eid2012.141026.

81. Azhar El, El-Kafrawy SA, Farraj SA, Hassan AM, Al-Saeed MS, Hashem AM, et al. Evidence for camel-to-human transmission of MERS Coronavirus. N Engl J Med. 2014. doi:10.1056/NEJMoa1401505.

82. Azhar El, Hashem AM, El-Kafrawy SA, Sohrab SS, Aburizaiza AS, Farraj SA, et al. Detection of the Middle East respiratory syndrome coronavirus genome in an air sample originating from a camel barn owned by an infected patient. MBio. 2014;5(4):e01450-14. doi:10.1128/mBio.01450-14.

83. Raj VS, Farag EA, Reusken CB, Lamers MM, Pas SD, Voermans J, et al. Isolation of MERS coronavirus from a dromedary camel, Qatar, 2014. Emerg Infect Dis. 2014;20(8):1339-42. doi:10.3201/eid2008.140663.

84. Woo PC, Wang M, Lau SK, Xu H, Poon RW, Guo R, et al. Comparative analysis of twelve genomes of three novel group $2 \mathrm{C}$ and group $2 \mathrm{~d}$ coronaviruses reveals unique group and subgroup features. J Virol. 2007; 81(4):1574-85. doi:10.1128/JVI.02182-06.

85. Lau SK, Li KS, Tsang AK, Lam CS, Ahmed S, Chen H, et al. Genetic characterization of Betacoronavirus lineage $C$ viruses in bats reveals marked sequence divergence in the spike protein of pipistrellus bat coronavirus HKU5 in Japanese pipistrelle: Implications for the origin of the novel Middle East respiratory syndrome coronavirus. J Virol. 2013;87(15):8638-50. doi:10.1128/JVI.01055-13.

86. Falcon A, Vazquez-Moron S, Casas I, Aznar C, Ruiz G, Pozo F, et al. Detection of alpha and betacoronaviruses in multiple Iberian bat species. Arch Virol. 2011;156(10):1883-90. doi:10.1007/s00705-011-1057-1.

87. Reusken CB, Lina PH, Pielaat A, de Vries A, Dam-Deisz C, Adema J, et al. Circulation of group 2 coronaviruses in a bat species common to urban areas in Western Europe. Vector Borne Zoonotic Dis. 2010;10(8):785-91. doi:10.1089/vbz.2009.0173.

88. De Benedictis P, Marciano S, Scaravelli D, Priori P, Zecchin B, Capua I, et al. Alpha and lineage $C$ betaCoV infections in Italian bats. Virus Genes. 2014; 48(2):366-71. doi:10.1007/s11262-013-1008-x.

89. Anthony SJ, Ojeda-Flores R, Rico-Chavez O, Navarrete-Macias I, ZambranaTorrelio CM, Rostal MK, et al. Coronaviruses in bats from Mexico. J Gen Virol. 2013;94(Pt 5):1028-38. doi:10.1099/vir.0.049759-0.

90. Annan A, Baldwin HJ, Corman VM, Klose SM, Owusu M, Nkrumah EE, et al. Human betacoronavirus 2c EMC/2012-related viruses in bats. Ghana and Europe Emerg Infect Dis. 2013;19(3):456-9. doi:10.3201/eid1903.121503.

91. Wacharapluesadee S, Sintunawa C, Kaewpom T, Khongnomnan K, Olival KJ, Epstein $\mathrm{JH}$, et al. Group C betacoronavirus in bat guano fertilizer. Thailand Emerg Infect Dis. 2013;19(8):1349-51. doi:10.3201/eid1908.130119.

92. Corman VM, Ithete NL, Richards LR, Schoeman MC, Preiser W, Drosten C, et al. Rooting the phylogenetic tree of middle East respiratory syndrome coronavirus by characterization of a conspecific virus from an African bat. J Virol. 2014;88(19):11297-303. doi:10.1128/JVI.01498-14.

93. Ithete NL, Stoffberg S, Corman VM, Cottontail VM, Richards LR, Schoeman $M C$, et al. Close relative of human Middle East respiratory syndrome coronavirus in bat. South Africa Emerg Infect Dis. 2013;19(10):1697-9. doi:10.3201/eid1910.130946.

94. Memish ZA, Mishra N, Olival KJ, Fagbo SF, Kapoor V, Epstein JH, et al. Middle East respiratory syndrome coronavirus in bats. Saudi Arabia Emerg Infect Dis. 2013;19(11):1819-23. doi:10.3201/eid1911.131172.

95. Yang L, Wu Z, Ren X, Yang F, Zhang J, He G et al. MERS-Related Betacoronavirus in Vespertilio superans Bats, China. Emerg Infect Dis. 2014; 20(7). doi:10.3201/eid2007.140318.

96. Lelli D, Papetti A, Sabelli C, Rosti E, Moreno A, Boniotti MB. Detection of coronaviruses in bats of various species in Italy. Viruses. 2013;5(11):2679-89. doi:10.3390/v5112679.

97. Yang Y, Du L, Liu C, Wang L, Ma C, Tang J, et al. Receptor usage and cell entry of bat coronavirus HKU4 provide insight into bat-to-human transmission of MERS coronavirus. Proc Natl Acad Sci U S A. 2014;111(34): 12516-21. doi:10.1073/pnas.1405889111.

98. Cui J, Eden JS, Holmes EC, Wang LF. Adaptive evolution of bat dipeptidyl peptidase 4 (dpp4): Implications for the origin and emergence of Middle East respiratory syndrome coronavirus. Virol J. 2013;10:304. doi:10.1186/1743-422X-10-304.

99. Graham RL, Donaldson EF, Baric RS. A decade after SARS: Strategies for controlling emerging coronaviruses. Nat Rev Microbiol. 2013;11(12):836-48. doi:10.1038/nrmicro3143.
100. Kupferschmidt K. The camel connection. Science. 2014;343(6178):1422-3. doi:10.1126/science.343.6178.1422. 5.

101. Xu RH, He JF, Evans MR, Peng GW, Field HE, Yu DW, et al. Epidemiologic clues to SARS origin in China. Emerg Infect Dis. 2004;10(6):1030-7. doi:10.3201/eid1006.030852.

102. Reed SE. The behaviour of recent isolates of human respiratory coronavirus in vitro and in volunteers: Evidence of heterogeneity among 229E-related strains. J Med Virol. 1984;13(2):179-92.

103. Corman VM, Baldwin HJ, Fumie Tateno A, Melim Zerbinati R, Annan A, Owusu $\mathrm{M}$ et al. Evidence for an ancestral association of human coronavirus 229E with bats. J Virol. 2015. doi:10.1128/JVI.01755-15.

104. Fouchier RA, Hartwig NG, Bestebroer TM, Niemeyer B, de Jong JC, Simon JH, et al. A previously undescribed coronavirus associated with respiratory disease in humans. Proc Natl Acad Sci U S A. 2004;101(16):6212-6. doi:10.1073/pnas.0400762101.

105. Fielding BC. Human coronavirus NL63: A clinically important virus? Future Microbiol. 2011;6(2):153-9. doi:10.2217/fmb.10.166.

106. Donaldson EF, Haskew AN, Gates JE, Huynh J, Moore CJ, Frieman MB. Metagenomic analysis of the viromes of three North American bat species: Viral diversity among different bat species that share a common habitat. J Virol. 2010;84(24):13004-18. doi:10.1128/JVI.01255-10.

107. Huynh J, Li S, Yount B, Smith A, Sturges L, Olsen JC, et al. Evidence supporting a zoonotic origin of human coronavirus strain NL63. J Virol. 2012;86(23):12816-25. doi:10.1128/JVI.00906-12.

\section{Submit your next manuscript to BioMed Central and take full advantage of:}

- Convenient online submission

- Thorough peer review

- No space constraints or color figure charges

- Immediate publication on acceptance

- Inclusion in PubMed, CAS, Scopus and Google Scholar

- Research which is freely available for redistribution 